\title{
MÉTODOS DE EXTRAÇÃo DE DNA PARA A DETECÇÃo DE Salmonella EM OVOS DE GALINHAS, COM E SEM CASCA, ATRAVÉS DA REAÇÃO EM CADEIA PELA POLIMERASE ${ }^{1}$
}

\author{
DNA EXTRACTION METHODS FOR Salmonella DETECTION IN CHICKEN EGGS, INSHELL AND \\ OUTSHELL, BY POLIMERASE CHAIN REACTION
}

\author{
Maristela Lovato Flôres ${ }^{2}$ Vladimir Pinheiro do Nascimento ${ }^{3}$ Ivonyr Irene Troglio Abdel Kader ${ }^{4}$ \\ Luciana Ruschel dos Santos ${ }^{5}$ Alexandre Pontes Pontes ${ }^{5}$ Carlos Tadeu Pippi Salle \\ Rui Fernando Felix Lopes $^{3}$
}

\section{RESUMO}

O diagnóstico microbiológico de Salmonella sp em amostras de alimentos é demorado, com cinco diferentes etapas, levando cerca de 120 horas até o resultado final. A utilização da técnica da Reação em Cadeia pela Polimerase (PCR) pode diminuir esse período, porém sofre influência de substâncias presentes na amostra que afetam a reação. $O$ objetivo deste trabalho foi comparar dois métodos de extração de DNA, a extração por tratamento térmico e a pelo fenol-clorofórmio, em amostras de 100 ovos de galinhas domésticas artificialmente contaminados com uma cepa de Salmonella enterica sorovar typhimurium em fase estacionária. $O$ material obtido com as extrações foi submetido à PCR, utilizando-se um par de iniciadores que amplificam um fragmento de $284 \mathrm{pb}$ do gene InvA de Salmonella sp. Comparando os métodos de extração, observou-se uma diferença na capacidade de deteccão de $12 \%$ a favor do método do fenol-clorofórmio, quando a extração foi realizada a partir do ovo com casca. No momento em que a mesma metodologia foi usada apenas com a parte interna dos ovos, essa diferença subiu para $26 \%$ o que foi significativo $(P<0,003)$, demonstrando que a metodologia de extração foi determinante para melhorar a sensibilidade da técnica. No entanto, ao comparar-se a percentagem de positivos independente da técnica de extração do DNA, observou-se diferença significativa $(P<0,047)$ a favor das amostras de ovos sem casca. Isso sugere que para a detecção de Salmonella por PCR deve-se utilizar apenas a parte interna dos ovos, pois a casca pode determinar interferência na técnica.

Palavras-chave: Salmonella, ovos, extração, DNA, PCR.

\section{SUMMARY}

The Salmonella sp detection in feed samples is time consuming, it has five stages and requires 120 hours for final results. The use of polimerase chain reaction technique can reduce this time considerably, however it can be affected by substances from the sample. This study had the objective of comparing two methods of DNA extraction, by heating process and by phenol-chloroform in samples of 100 chicken eggs experimentally infected with a sample of Salmonella enterica sorovar typhimurium in stationary phase. After the two extraction methods a PCR was done using a pair of oligonucleotides that amplifies a fragment of $284 \mathrm{pb}$ in the InvA gene de Salmonella sp. Comparing the extraction methods it was noted a difference of $12 \%$ favorably to the phenol-chloroform method when the extraction was done from eggs with shell. The same method using just the egg internal part resulted in a difference of $26 \%$ with high significance $(P<0.003)$, showing that the method used was determinant to improve the technique efficiency. However, comparing the positive percentage independent of the DNA extraction method a significant difference $(P<0.047)$ was noted for outshell eggs. This fact suggests that for Salmonella egg analysis, only the egg internal part should be used because the shell can determine interference in technique.

Key words: Salmonella, eggs, extraction, DNA, PCR.

\section{INTRODUÇÃO}

A busca da metodologia ideal para o diagnóstico das salmoneloses nos animais, nos alimentos e no homem começou no momento da sua descrição como agente patogênico e permanece até hoje. Várias alternativas têm sido pesquisadas como imunoensaios, imunodifusão, aglutinação em látex, e hibridização do DNA (BLACKBURN,1993).

\footnotetext{
${ }^{1}$ Parte da Tese de Doutorado do primeiro autor, no Programa de Pós-graduação em Ciências Veterinárias da Universidade Federal do Rio Grande do Sul (UFRGS), Apoio financeiro: FAPERGS, FINEP, FFFCMPA, Cenbiot ${ }^{\text {Enzimas }}$, UFRGS, CDPA-UFRGS, FIPE-UFSM.

${ }^{2}$ Médico Veterinário, Professor Adjunto, MSc., Departamento de Medicina Veterinária Preventiva, UFSM, Santa Maria - RS, $97105-$ 900. E.mail: patoaves@ccr.ufsm.br. Autor para correspondência.

${ }^{3}$ Médico Veterinário, Professor Adjunto, PhD., UFRGS.

${ }^{4}$ Farmacêutico, Professor Titular, Doutor. Fundação Faculdade Federal de Ciências Médicas de Porto Alegre.

${ }^{5}$ Médico Veterinário, Programa de Pós-graduação em Ciências Veterinárias, UFRGS.
} 
A ocorrência de surtos de intoxicação alimentar por salmonelas em diversos países chamou a atenção para fontes comuns de infecção. As investigações epidemiológicas identificaram o consumo de ovos ou alimentos contendo ovos como responsáveis pela maioria dos surtos. PINTO (1999), ao examinar os dados coletados no Rio Grande do Sul, das enfermidades transmitidas por alimentos, pela Secretaria da Saúde e do Meio Ambiente, relata semelhança com as informações de outros lugares do mundo, como os alimentos mais frequientemente envolvidos e os agentes causais.

Os métodos analíticos para pesquisa de Salmonella em ovos e outros produtos, definem como sendo o diagnóstico bacteriológico com isolamento e identificação do agente a técnica oficial recomendada (BRASIL, 1995), porém muitas pesquisas têm sido realizadas visando a introduzir metodologias rápidas e sensíveis para enfrentarem a agilidade que o mercado atual exige.

O desenvolvimento de testes de imunocaptura (IMS) e amplificação do DNA pela Reação em Cadeia pela Polimerase (PCR) ou biosensores trouxe mais rapidez e precisão, com resultados sendo obtidos em torno de 24 horas (BAILEY \& COX,1996). Além disso, OYARZÁBAL (1996) observou que a PCR foi a técnica de maior aceitação entre as demais técnicas moleculares desenvolvidas recentemente, podendo ser empregada como ferramenta de diagnóstico em laboratórios clínicos.

KONGMUANG et al.(1994) citam que o custo de cada método é também uma preocupação. Tanto partículas como substâncias solúveis são parcialmente removidas por centrifugação de baixa e alta velocidade. Entretanto, algumas bactérias poderiam ser perdidas no processo, bem como a permanência de substâncias que podem interferir na PCR, levando à diminuição da sensibilidade da técnica.

RAHN et al. (1992), usando um par de oligonucleotídeos do gene InvA, detectaram com sucesso 626 cepas de Salmonella em 630 testadas, a partir de uma colônia isolada e incorporada direto na PCR, obtendo uma sensibilidade de $99,4 \%$ e especificidade de $100 \%$, pois não observou reação positiva em nenhum controle negativo pertencentes a outras 33 enterobactérias testadas.

Neste trabalho, testaram-se duas metodologias de extração de DNA bacteriano, a partir de ovos de galinhas domésticas com casca e sem casca, contaminados artificialmente com Salmonella typhimurium e analisados por PCR.

\section{MATERIAL E MÉTODOS}

Foram contaminados 100 ovos SPF (specific pathogen free) com $1 \mathrm{~mL}$ de um cultivo de Salmonella typhimurium, resistente ao ácido nalidíxico e à spectinomicina, em fase estacionária com cerca de $3,0 \times 10^{8}$ células. Após a desinfecção dos ovos com álcool iodado, eles foram abertos com assepsia e, em seu conteúdo interno, foi adicionado o inóculo, seguiu-se a homogeneização. Dessa mistura, foi pesada $25 \mathrm{~g}$ e adicionada em $225 \mathrm{~mL}$ de água peptonada a $1 \%$, homogeneizadas em stomacher por 30s em baixa agitação e incubados a $42^{\circ} \mathrm{C} / 24$ horas, quando foram colhidas amostras de $1 \mathrm{~mL}$ para os procedimentos de extração e posterior PCR.

As amostras de ovo total, com casca, foram obtidas pela trituração do ovo em saco plástico esterilizado e seguiu-se o mesmo procedimento já descrito para a parte interna dos ovos.

As metodologias de extração do DNA utilizadas foram as seguintes: tratamento térmico, constando de centrifugação inicial a $2.040 \mathrm{~g} / 4 \mathrm{~min}$, descarte do sobrenadante e acréscimo de $1,0 \mathrm{~mL}$ de tampão TE (Tris+EDTA). Seguindo-se de agitação em vortex, centrifugação a $2.040 \mathrm{~g} / 5 \mathrm{~min}$, descarte do sobrenadante e acréscimo de $350 \mu \mathrm{L}$ de $\mathrm{TE}$, novo vortex. O aquecimento ocorreu em bloco térmico (Baxter Scientific Products), a $95^{\circ} \mathrm{C} / 5 \mathrm{~min}$, seguido de centrifugação rápida em microcentrífuga; logo após, coletou-se o sobrenadante para a PCR. A extração pelo fenol-clorofórmio seguiu protocolo descrito por SAMBROOK et al. (1989).

O par de iniciadores (GibcoBRL) consistiu de uma seqüência do gene Inv A, citada por RANH et al. (1992), com uma amplificação esperada de $284 \mathrm{pb}$, utilizado neste experimento com uma concentração de $5,0 \mathrm{nmo} \ell / \mathrm{mL}$.

A PCR foi realizada em aparelho termocilador (Perkim Elmer gene Amp PCR system 2400, New Jersey, USA) com um volume final de $25 \mu \mathrm{L}$, constando de $16,3 \mu \mathrm{L}$ de água miliQ, $0,5 \mu \mathrm{L}$ da enzima Taq DNA polimerase

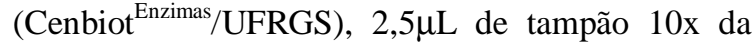

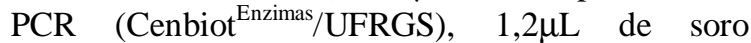
albumina bovina (Sigma), 2,0 $\mu \mathrm{L}$ da mistura de dNTPs (5mM, GibcoBRL), 0,5 $\mu \mathrm{L}$ de cada par de iniciadores e $1,0 \mu \mathrm{L}$ da amostra. Em todas reações, foram adicionados controles negativos, sem DNA, no lugar da amostra. Os controles positivos foram amostras de DNA de Salmonella typhimurium com $63 \mathrm{ng} / \mu \ell$.

A PCR obedeceu aos seguintes ciclos: $95^{\circ} \mathrm{C} / 1$ minuto para desnaturação inicial; $94^{\circ} \mathrm{C} / 1$ minuto, 30 ciclos; $54^{\circ} \mathrm{C} / 30$ segundos, 30 ciclos; $72^{\circ} \mathrm{C} / 1$ minuto, 30 ciclos e $72^{\circ} \mathrm{C} / 7$ minutos para a extensão final. Os produtos da PCR foram analisados em gel de agarose a $2 \%$, contendo brometo de

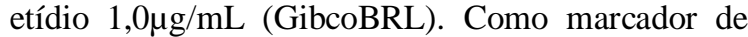
peso molecular utilizou-se DNA ladder $100 \mathrm{pb}$ (GibcoBRL), a visualização foi realizada em apare- 
lho transiluminador (Pharmacia LKB, Macrouve) e fotografados com câmara polaróide.

A análise estatística efetuada pelo teste do Qui-quadrado em que foram comparados os resultados positivos e negativos em ambos os métodos de extração e entre as amostras procedentes de ovos sem ou com casca, independentemente do método de extração.

\section{RESULTADOS E DISCUSSÃO}

A comparação entre os dois métodos de extração do DNA utilizados no experimento pode ser observada na tabela 1 , em amostras de ovos com casca, não sendo possível detectar diferença estatística significativa, mesmo em simulação estatística com número maior de amostras.

Os $12 \%$ de diferença entre amostras positivas na extração pelo método do fenol 36/50, contra 30/50 no tratamento térmico, demonstram que a metodologia do fenol determinou detecção de salmonelas em maior número de amostras, sugerindo que a perda de identificação destes seis ovos na metodologia pelo tratamento térmico poderiam determinar prejuízos importantes à saúde pública.

Na tabela 2, a avaliação foi realizada apenas com uma mistura da parte interna dos ovos, comparando os dois métodos de extração da mesma forma que com o ovo total. A diferença a favor da metodologia do fenol subiu para $26 \%$, sendo estatisticamente significativa $(\mathrm{P}<0,003)$. A recuperação de ovos contaminados melhorou bastante mas não suficiente. Vários fatores podem ter favorecido a ocorrência destes resultados nos quais a coagulação das proteínas dos ovos, ao serem submetidos ao aquecimento, pode ter influenciado na retenção do DNA bacteriano. Outro aspecto é a purificação da amostra que é efetuada na extração pelo fenol em que resíduos provenientes dos ovos, interferentes à PCR, tenham sido eliminados.

No diagnóstico clínico, no entanto, os números das tabelas 1,2 e 3 são o bastante para concluir-se que é necessário estudos com outros métodos de extração e purificação de DNA para melhorar a recuperação das salmonelas presentes em ovos, uma vez que a sensibilidade máxima obtida foi

Tabela 1 - Comparação entre os métodos de extração de DNA na detecção de Salmonella typhimurium em ovos com casca pela PCR.

\begin{tabular}{|c|c|c|c|c|c|c|}
\hline \multirow[t]{2}{*}{ Resultado } & \multicolumn{2}{|c|}{ Tratamento Térmico } & \multicolumn{2}{|c|}{ Fenol } & \multicolumn{2}{|c|}{ Total } \\
\hline & $\mathrm{N}$ & $\%$ & $\mathrm{~N}$ & $\%$ & $\mathrm{~N}$ & $\%$ \\
\hline Positivo & 30 & 60,00 & 36 & 72,00 & 66 & 66,00 \\
\hline Negativo & 20 & 40,00 & 14 & 28,00 & 34 & 34,00 \\
\hline Total & 50 & 100,00 & 50 & 100,00 & 100 & 100,00 \\
\hline
\end{tabular}

$\mathrm{X}^{2}=1,60(\mathrm{P}>0,05)$
Tabela 2 - Comparação entre os dois métodos de extração de DNA, realizados da parte interna dos ovos, na detecção de $\mathbf{S a l}$ monella typhimurium pela PCR

\begin{tabular}{lcccrrr}
\hline \multirow{2}{*}{ Resultado } & \multicolumn{2}{c}{ Térmico } & \multicolumn{2}{c}{ Fenol } & \multicolumn{2}{c}{ Total } \\
& $\mathrm{N}$ & $\%$ & $\mathrm{~N}$ & $\%$ & $\mathrm{~N}$ & $\%$ \\
\hline Positivo & 30 & $60,00^{\mathrm{b}}$ & 43 & $86,00^{\mathrm{a}}$ & 73 & 73,00 \\
Negativo & 20 & $40,00^{\mathrm{a}}$ & 07 & $14,00^{\mathrm{b}}$ & 27 & 27,00 \\
Total & 50 & 100,00 & 50 & 100,00 & 100 & 100,00 \\
\hline
\end{tabular}

$\mathrm{X}^{2}=8,57(\mathrm{P}<0,003)$.

$\mathrm{a}, \mathrm{b}=$ letras diferentes indicam percentuais estatisticamente diferentes pelo teste do $\mathrm{X}^{2}$.

de $86 \%$ na metodologia de extração pelo fenolclorofórmio, em amostras contendo apenas a parte interna dos ovos.

Dois métodos de extração de DNA bacteriano presente em alimentos foram testados por DICKINSON et al.(1995). O primeiro, com lise rápida, usando um tampão com proteinase $\mathrm{K}$, para lisar as células e solubilizar as amostras. $\mathrm{O}$ segundo, com tolueno e mutanolisina para lise celular e solubilização com tiocinato de guanidina. Em ambas extrações, o DNA foi precipitado com isopropanol, obtendo resultados semelhantes ao comparar os dois métodos de extração.

LAGATOLLA et al. (1996), ao realizar PCR para detectar salmonelas provenientes de diferentes materiais clínicos e conservadas no meio de Luria-Bertani, compararam dois métodos de extração de DNA, o primeiro com fenol-clorofórmio e o segundo com tratamento pelo calor a $95^{\circ} \mathrm{C} /$ 10minutos. Após uma primeira etapa idêntica com a utilização de lisozima, duodecil sulfato e proteinase $\mathrm{K}$, da mesma forma não observaram diferença significativa entre as metodologias testadas.

Ao fazer-se a comparação entre os totais de positivos nas tabelas 1 e 2, obteve-se a tabela 3 , com resultados que mostram ser a parte interna dos ovos, a porção mais indicada para diagnóstico de salmonelas por PCR, independente da metodologia de extração utilizada.

A realização da PCR direto de material clínico, alimentos ou cultivos têm sido possível, mas determinados procedimentos de extração incrementam sua performance, uma vez que diferentes substâncias presentes nas amostras clínicas como, concentrações elevadas de proteínas, de íons cálcio, sais biliares ou componentes de meios de cultivo podem inibir a técnica (ROSSEN et al., 1992).

A composição química do ovo total da galinha sem casca é de $74 \%$ de água, $13 \%$ de proteína, $11 \%$ de gordura, $0,7 \%$ de hidratos de carbono, com concentrações elevadas de cálcio, fósforo, sódio, potássio, cloro e magnésio. A casca possui $98 \%$ de substâncias inorgânicas, dos quais $95 \%$ são car 
Tabela 3 - Comparação entre os totais de amostras positivas para Salmonella colhidas de ovos com casca e sem casca e submetidas à PCR.

\begin{tabular}{lcccc}
\hline \multirow{2}{*}{ Resultado } & \multicolumn{2}{c}{ Ovos com casca } & \multicolumn{2}{c}{ Ovos sem casca } \\
& N & $\%$ & N & $\%$ \\
\hline Positivo & 66 & $66,00^{\mathrm{b}}$ & 73 & $73,00^{\mathrm{a}}$ \\
Negativo & 34 & $34,00^{\mathrm{b}}$ & 27 & $27,00^{\mathrm{a}}$ \\
Total & 100 & 100,00 & 10 & 100,00 \\
\hline
\end{tabular}

$\mathrm{X}^{2}=3,956(\mathrm{P}<0,047)$.

$\mathrm{a}, \mathrm{b}$ - letras diferentes indicam percentuais estatisticamente diferentes pelo teste $X^{2}$.

Bonato de cálcio e o restante composto de carbonato de magnésio e fosfato tricálcio (FEHLHABER \& JANETSCHKE,1995), constituintes que poderiam causar interferências semelhantes às citadas por ROSSEN et al. (1992).

Ao compararem-se os custos das metodologia empregadas, a extração térmica é duas vezes mais barata que a pelo fenol-clorofórmio, pois nas condições em que se realizou o experimento, os procedimentos de extração custaram, por amostra, $\mathrm{R} \$ 1,80$ pelo tratamento térmico e $\mathrm{R} \$ 4,24$ pelo fenol-clorofórmio. Ainda, teve-se o envolvimento de um tempo de cerca de seis horas a mais para completar-se a metodologia do fenol-clorofórmio com muita manipulação das amostras, podendo favorecer contaminações cruzadas ou perda do DNA alvo.

A tecnologia da PCR, incluindo os equipamentos necessários, não é inacessível, comparada com equipamentos e materiais utilizados para um teste de ELISA; em algumas situações, o teste de ELISA é mais caro. A formação de pessoal habilitado é outro fator a ser discutido, porém muito difícil de avaliar-se, pois nota-se que a metodologia da PCR depois de padronizada é de fácil execução.

\section{CONCLUSÕES}

Com esses resultados, pode-se concluir que a metodologia de extração de DNA pelo fenolclorofórmio, da forma aqui empregada foi mais efetiva na recuperação de salmonelas em ovos, tanto com casca $(72 \%)$, como sem casca $(86 \%)$. A favor da metodologia térmica, tem-se o tempo de diagnóstico, reduzido em seis horas, pouca manipulação das amostras e custo menor.

A pesquisa de outras metodologias de extração poderão determinar melhor sensibilidade da técnica para detecção de salmonelas em ovos e definir se a presença da casca inibiu a técnica, sugerindo testes com diferentes quantidades de casca.
Essa influência da casca na PCR, ou na quantidade de DNA recuperado no processo de extração, permite concluir que a análise de ovos por PCR deve ser realizada a partir apenas do seu conteúdo interno.

\section{REFERÊNCIAS BIBLIOGRÁFICAS}

BAILEY, J.S., COX, N.A. Detecting specific Salmonella strains. World Poultry, Special for Salmonella, Netherlands, May, p.18-19, 1996.

BRASIL, Ministério da Agricultura, do Abastecimento e da Reforma Agrária, Secretaria da Defesa Agropecuária. Método Analítico de Carcaças de Aves e Pesquisa de Salmonella. Diário Oficial da União, Brasília, Portaria $\mathrm{n}^{\circ} .08$ de 23/01/1995, p.1182-1184, em 27/01/95.

BLACKBURN, C.W. A review, rapid and alternative methods for the detection of Salmonellas in foods. Journal of Applied Bacteriology, Oxford, v.3, n.75, p.199-214, 1993.

DICKINSON, J.H., KROLL, R.G., GRANT, K.A. The direct application of polymerase chain reaction to DNA extracted from foods. Letters in Applied Microbiology, v.20, p.212$216,1995$.

FEHLHABER, K. \& JANETSCHKE, H. Higiene veterinária de los alimentos. Acribia : Zaragoza, 1995. 660p.

KONGMUANG, U., LUK, J.M.C., LINDBERG, A.A. Comparison of three stool processing methods for detection of Salmonella serogroups B, C2 and D by PCR. Journal of Clinical Microbiology, Washington, v.32, n.12 p.3072-3074, 1994.

LAGATOLlA, C., DOLZANI, L., TONIN, E. et al. PCR ribotyping for characterizing Salmonella isolates of different serotypes. Journal of Clinical Microbiology, Washington, v.34, n.10, p.2440-2443, 1996.

PINTO, A.T. Ocorrência de enfermidades bacterianas transmitidas por alimentos no estado do Rio Grande do Sul. Porto Alegre, RS,1999. 124p. Dissertação (Mestrado em Ciências Veterinárias) - Programa de Pós-graduação em Ciências Veterinárias, Universidade Federal do Rio Grande do Sul, 1999.

OYARZÁBAL, O.A. Técnicas moleculares para o diagnóstico de patógenos aviários. Avicultura Professional, v.14, n.16, p.19-21, 1996.

RAHN, K., De GRANDIS, S.A., CLARKE, R.C. $\boldsymbol{e} t \boldsymbol{a l}$. Amplification of InvA gene sequence of Salmonella typhimurium by polymerase chain reaction as a specific method of detection of Salmonella. Molecular and Cellular Probes. London, v.6, p.271-279, 1992.

ROSSEN, L., NORSKOV, P., HOLMSTROM, K. et al. Inhibition of PCR by components of food samples, microbial diagnostic assays and DNA extraction solutions. International Journal of Food Microbiology, v.17, p.37-45, 1992.

SAMBROOK, J., FRITCSH, E.F., MANIATIS, T. Molecular cloning: A laboratory manual. 2. ed. New York : Cold Spring Harbor Laboratory, 1989. 3v. 3104p. 